\title{
Family Preparedness in Caring Patients with Cancer: A Literature Review
}

\author{
Akbar U Saun, Erna Rochmawati \\ Universitas Muhammadiyah Yogyakarta, Indonesia \\ Corespondending author: akbarusaun@yahoo.com
}

\begin{abstract}
Background: Cancer patients choose to understand at home. Families have an important role in the care of clients specifically at home. Readiness is needed in order to provide optimal care and will be able to improve the quality of life of patients. This literature review aims to see how families are prepared to care for patients with cancer at home.

Purpose: The objective of this research was to analyze the journal literature about family readiness to treat patients at home needs to be considered and nurses play an important role in providing education to the family in providing patient care at home so that the patient's welfare is fulfilled.

Methods: Writing this journal literature uses study literature originating from the database, namely EBSCO, PROQUEST, PubMed, and Google Scholar using the keywords Family Preparedness, Family Caregiver, Symptom Management, Palliative Care, family quality of life, Care Parenting. Using inclusion criteria that contain literature sources taken from 2009 to 2019, inclusion criteria, using English, conformity of approval keywords, linkages between the results of literature research and the discussion raised.

Results: There are 4 themes found in this literature review, namely family care in patient care, instruments in measuring family readiness, self-affection for families who care for patients at home, and psycho-education in increasing family readiness to care for patients at home.

Conclusion: Family readiness to treat patients at home needs to be considered. Nurses play an important role in providing education to the family in providing patient care at home so that the patient's welfare is fulfilled.
\end{abstract}

Keywords: Family Preparedness, Family Caregiver, Symptom Management, Palliative Care, Caregiving Burden. 


\section{BACKGROUND}

Cancer is one of the most deadly chronic diseases in the world. According to US statistics, the number of deaths from cancer is around $23 \%$ of the total number of deaths in the country and is the second most deadly disease after heart disease (Anand et al., 2008). The World Health Organization (WHO) said cancer was the main cause of first or second death in humans before reaching the age of 70 years, in 91 of 172 countries (McGuire, S. 2016).

The proportion of cancer patients who live depending on the help of their family caregivers increases significantly. By 2020, the number of people with cancer is estimated to swell by $31 \%$ from 13 to more than 18 million. Family care for patients at home is very important to optimize the quality of life and well-being of patients, especially cancer patients (Silveira et al., 2018). Families as caregivers of patients at home often feel unprepared in handling patients. This level of readiness is an important factor to improve their welfare. This readiness refers to how ready families carry out their duties and demands in carrying out their roles as caregivers of patients at home (Hendrix et al., 2016).

Care of patients at home will increase patients' sense of security and comfort in life-threatening problems by providing palliative care needs at home (Sarmento et al., 2017). Caregivers of patients, especially patients with cancer at home, often face huge demands during a disease recovery program, when giving services, and during mourning. caregiver burden, needs, satisfaction, quality of life, and how home care is often not monitored by the clinic so that the need to deal with problems in patients at home is not fulfilled and can cause undesirable problems (Tanco et al., 2017). This literature review aims to discuss how family preparedness includes anything (instrument, burden?) In caring for patients with cancer and other life-threatening diseases at home.

\section{OBJECTIVE}

The objective of this research was to analyze the journal literature about family readiness to treat patients at home needs to be considered and nurses play an important role in providing education to the family in providing patient care at home so that the patient's welfare is fulfilled.

\section{METHODS}

Writing this literature review comes from the theoretical concepts of the research under study. Data collection was carried out by filtering 18606 literature sources into 8 related literature which were discussed in the writing of the literature review. There are inclusion criteria used in filtering literature that are suitable for topics taken such as families caring for patients with cancer, paliative care. The specified criteria are literature sources taken from 2009 to 2019, suitability of writing keywords, journals with English, the relevance of the results of literature writing with discussion. In journal collection, searches are conducted through several accredited journal search sites such as PROQUEST, PubMed, and Google Scholar. The keywords used in the search for literature related to this topic are "family preparedness OR caregiver AND symptom management family AND palliative care AND caregiving burden".

Table 1. Literature Search Strategy

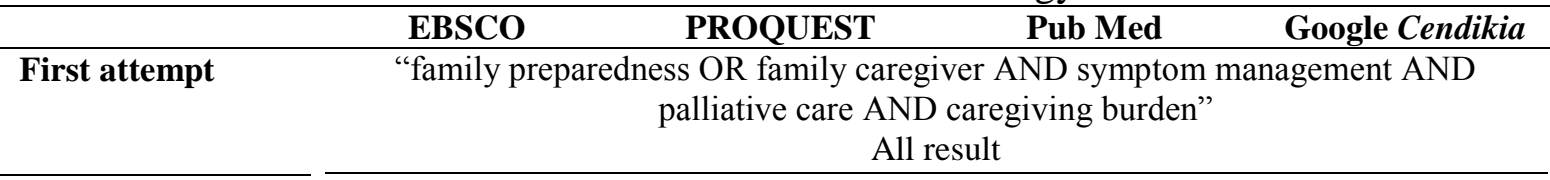


Journal Of Nursing Practice

http://thejnp.org

ISSN: 2614-3488 (print); 2614-3496 (online)

Vol.3 No.2. April 2020. Page.143-152

\begin{tabular}{|c|c|c|c|c|}
\hline & 693 articles & 415 articles & 198 articles & 17.300 articles \\
\hline \multirow[t]{3}{*}{ Second attempt } & $\begin{array}{c}\text { Filter by years } \\
(2009-2019)\end{array}$ & $\begin{array}{c}\text { Filter by years } \\
(2009-2019)\end{array}$ & $\begin{array}{c}\text { Filter by years } \\
(2009-2019)\end{array}$ & $\begin{array}{c}\text { Filter by years } \\
(2009-2019)\end{array}$ \\
\hline & $\begin{array}{c}\text { Abstract and Full } \\
\text { Text } \\
\text { Scholary journal } \\
\text { Academic Journal }\end{array}$ & $\begin{array}{c}\text { Abstract and Full } \\
\text { Text }\end{array}$ & $\begin{array}{c}\text { Abstract and Full } \\
\text { Text }\end{array}$ & $\begin{array}{c}\text { Abstract and Full } \\
\text { Text }\end{array}$ \\
\hline & 110 articles & 205 articles & 109 articles & 6.231 articles \\
\hline \multirow[t]{2}{*}{ Third attempt } & \multicolumn{3}{|c|}{ Inclution } & Abstract and Full Text \\
\hline & 85 articles & 107 articles & 46 articles & 1.806 articles \\
\hline \multirow[t]{2}{*}{ Fourth attempt } & \multicolumn{3}{|c|}{ Include } & Abstract and Full Text \\
\hline & 0 articles & 3 articles & 3 articles & 2 articles \\
\hline
\end{tabular}

\section{Data Analysis}

Data analysis is done by looking at the literature writing year (2009-2019), reading abstracts from selected research journals, reading the research journal skimming if the abstract does not explain several points in the journal, then marking / recording important things and their relevance to the research problem appointed. Recording sources of information is also done in analyzing this data to prevent elements of plagiarism. Information obtained based on notes, quotes, or information is arranged systematically so that it can be easily searched if needed at any time.

The use of characteristic studies is intended to make it easier to make conclusions from the journal obtained. The study of these characteristics contains the name of the author and the year of journal writing, the research design used, the intervention provided, the number of samples, instruments, and results. From the results obtained, the author will analyze each of these results in order to see how the family's readiness in treating patients at home, especially in cancer patients. The inclusion criteria used in this literature are articles that use English, a publication journal with a range from 2009 to 2019, and articles in full text. Exclusion criteria used in executing journals that are not used include, among other things, incomplete articles, usually there are only abstracts and books.

How is the readiness of the family in the caregivers of patients with cancer, the preparation of the family in treating patients at home is the main focus in writing this literature review. A total of 18,606 journals were searched in several journal search sites, then excluded studies were carried out by including the inclusion criteria, namely families caring for cancer patients and paliative care, so that the total journals that met the requirements and used in the literature review were 8 journals.

Table 2. Study of Characteristics of Literature

\begin{tabular}{|c|c|c|c|c|c|}
\hline $\begin{array}{l}\text { Authors } \\
\text { (Year) }\end{array}$ & Conflict of Theory & Study design & Sample & Instrument & Implication \\
\hline $\begin{array}{l}\text { (Grant et } \\
\text { al., 2013) }\end{array}$ & $\begin{array}{l}\text { The diagnosis of } \\
\text { cancer that is of } \\
\text { concern is the patient } \\
\text { and his family. The } \\
\text { care provider at } \\
\text { home, namely the } \\
\text { family is a social unit } \\
\text { that can make a } \\
\text { negative impact on } \\
\text { the cancer }\end{array}$ & $\begin{array}{l}\text { Quantitative, } \\
\text { descriptive }\end{array}$ & $\begin{array}{l}163 \\
\text { participa } \\
\text { nts }\end{array}$ & $\begin{array}{l}\text { Questionnair } \\
\mathrm{e}\end{array}$ & $\begin{array}{l}\text { Caregivers experience a } \\
\text { high level of caregiver } \\
\text { burden and report a decrease } \\
\text { in psychological well-being } \\
\text { and overall quality of life. }\end{array}$ \\
\hline
\end{tabular}


continuum, from the beginning of the diagnosis of the disease to the end of his life (Ferrell \& Mazanec, 2009; Given, Given, \& Sherwood, 2012; Lewis, 2004)

(Hendrix Having a life with a et al., diagnosis of cancer 2016) creates difficulties for both the patient and the family caring for them at home. Self-efficacy is an important concept in parenting because it is a prerequisite for delivering actions that are actually good and right for patients. Enhanced-CT is known as a protocol that teaches the knowledge and skills of caregivers to manage symptoms and

strategies for managing their own psychological stress as carers for cancer patients at home.

(Chih et The pattern of

al., 2013) parenting carried out by families with cancer patients is Quantitative, intervention, RCT
Quantitative, intervention, RCT

138
participa
nts

Questionnair The Enhanced-CT Protocol

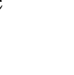
management of symptoms and stress when giving care to patients at home. is given to improve family
self-efficacy in the something that needs to be considered. Follow-up care for cancer patients at home is the responsibility of the family caring at home so that it requires care management in terms of symptoms that occur in the patient appropriately.

Management of this symptom must be done well and on time, therefore the online symptom reporting system 


\begin{tabular}{|c|c|c|c|c|c|c|}
\hline & $\begin{array}{l}\text { may be a way that } \\
\text { can be applied to } \\
\text { reduce family burden } \\
\text { in providing care at } \\
\text { home. }\end{array}$ & & & & & \\
\hline $\begin{array}{l}\text { (Anette } \\
\text { Henriksso } \\
\text { n et al., } \\
2015)\end{array}$ & $\begin{array}{l}\text { The validity and } \\
\text { reliability of an } \\
\text { instrument is needed } \\
\text { to find out how } \\
\text { effective the } \\
\text { instrument is used to } \\
\text { measure the level of } \\
\text { family readiness in } \\
\text { handling patients at } \\
\text { home. The } \\
\text { Preparedness } \\
\text { Caregiving Scale has } \\
\text { items that capture } \\
\text { various levels of } \\
\text { preparedness. }\end{array}$ & Quantitative & & $\begin{array}{l}647 \\
\text { participa } \\
\text { nts }\end{array}$ & $\begin{array}{l}\text { Questionnair } \\
\mathrm{e}\end{array}$ & $\begin{array}{l}\text { The Preparedness for Care } \\
\text { Scale (PCS) is a } \\
\text { measurement scale that is } \\
\text { effective in measuring the } \\
\text { level of family readiness in } \\
\text { providing care for patients } \\
\text { with palliative care at home. } \\
\text { PCS can be used by all } \\
\text { genders, ages and } \\
\text { languages. }\end{array}$ \\
\hline $\begin{array}{l}\text { (Anette } \\
\text { Henriksso } \\
\text { n \& \& } \\
\text { Årestedt, } \\
\text { 2013) }\end{array}$ & $\begin{array}{l}\text { Families } \\
\text { caregivers of patients } \\
\text { at home often feel } \\
\text { unprepared in } \\
\text { handling patients. } \\
\text { This level of } \\
\text { readiness is an } \\
\text { important factor to } \\
\text { improve their } \\
\text { welfare. This } \\
\text { readiness refers to } \\
\text { how ready the family } \\
\text { carries out tasks and } \\
\text { demands in carrying } \\
\text { out its role as } \\
\text { caregivers of patients } \\
\text { at home. }\end{array}$ & $\begin{array}{l}\text { Quantitative, } \\
\text { sectional }\end{array}$ & cross & $\begin{array}{l}125 \\
\text { participa } \\
\text { nts }\end{array}$ & $\begin{array}{l}\text { Questionnair } \\
\mathrm{e}\end{array}$ & $\begin{array}{l}\text { The level of patient } \\
\text { readiness is significantly } \\
\text { related to life expectancy, } \\
\text { higher appreciation, and } \\
\text { reduced anxiety. Readiness } \\
\text { in treating patients at home } \\
\text { is very important when } \\
\text { caregivers experience a } \\
\text { problematic situation in a } \\
\text { patient or the patient shows } \\
\text { life-threatening symptoms. } \\
\text { The psycho-education } \\
\text { support model is considered } \\
\text { important to improve } \\
\text { caregiver readiness in } \\
\text { handling patients at home. }\end{array}$ \\
\hline $\begin{array}{l}\text { (Fujinami } \\
\text { et al., } \\
\text { 2015) }\end{array}$ & $\begin{array}{l}\text { Caregivers } \\
\text { patients at home } \\
\text { often have a } \\
\text { psychological } \\
\text { decline because of } \\
\text { the stress they } \\
\text { experience in } \\
\text { handling patients at } \\
\text { home. The need to } \\
\text { know what kinds of } \\
\text { problems are usually } \\
\text { experienced by } \\
\text { caregivers so that } \\
\text { more attention is } \\
\text { given to the } \\
\text { appropriate } \\
\text { interventions } \\
\text { handle them. }\end{array}$ & Quantitative & & $\begin{array}{l}163 \\
\text { participa } \\
\text { nts }\end{array}$ & $\begin{array}{l}\text { Questionnair } \\
\mathrm{e}\end{array}$ & $\begin{array}{l}\text { There are several types of } \\
\text { problems experienced by } \\
\text { caregivers in providing care } \\
\text { to cancer patients. Among } \\
\text { them are self-care problems } \\
\text { and maintenance of quality } \\
\text { of life, components of } \\
\text { caregiver roles, and } \\
\text { components of stress } \\
\text { caregivers. This can be used } \\
\text { as a reference for any } \\
\text { components that need to be } \\
\text { considered in terms of the } \\
\text { challenges experienced by } \\
\text { patient caregivers, namely } \\
\text { families in providing patient } \\
\text { care at home. }\end{array}$ \\
\hline $\begin{array}{l}\text { (Dionne- } \\
\text { Odom et }\end{array}$ & $\begin{array}{l}\text { Caregivers r of } \\
\text { patients at home }\end{array}$ & Quantitative & & $\begin{array}{l}294 \\
\text { paticipan }\end{array}$ & $\begin{array}{l}\text { Questionnair } \\
\text { e }\end{array}$ & $\begin{array}{l}\text { Most caregivers are not } \\
\text { much involved in the }\end{array}$ \\
\hline
\end{tabular}


Journal Of Nursing Practice

http://thejnp.org

ISSN: 2614-3488 (print); 2614-3496 (online)

Vol.3 No.2. April 2020. Page.143-152

\begin{tabular}{|c|c|c|c|c|c|}
\hline al., 2017) & $\begin{array}{l}\text { have a level of well- } \\
\text { being in patient care } \\
\text { and self-affirmation } \\
\text { or how they make } \\
\text { different decisions. } \\
\text { The need to know } \\
\text { what the impact is } \\
\text { and is accepted by } \\
\text { adult patients with } \\
\text { cancer who have a } \\
\text { poor prognosis in } \\
\text { each family care with } \\
\text { these different } \\
\text { components. }\end{array}$ & & ts & & $\begin{array}{l}\text { practice of self-care, } \\
\text { depression and anxiety and } \\
\text { mental health of cancer } \\
\text { sufferers. The need for } \\
\text { interventions to improve } \\
\text { caregiver welfare, } \\
\text { preparedness, and self- } \\
\text { efficacy in order to increase } \\
\text { health responsibility, stress } \\
\text { management, interpersonal } \\
\text { relationships, and self-care } \\
\text { practices and grow the } \\
\text { spiritual role of patients at } \\
\text { home. }\end{array}$ \\
\hline $\begin{array}{l}\text { (Annette } \\
\text { Henriksso } \\
\text { n, } \\
\text { Andershe } \\
\text { d, } \\
\text { Benzein, } \\
\& \\
\text { Årestedt, } \\
\text { 2012) }\end{array}$ & $\begin{array}{l}\text { Families have a big } \\
\text { responsibility in } \\
\text { managing patients } \\
\text { who need care at } \\
\text { home. Family } \\
\text { readiness, } \\
\text { competence, and } \\
\text { rewards available to } \\
\text { reduce negative risks } \\
\text { related to care } \\
\text { provided. There are } \\
\text { several instruments } \\
\text { to measure all three, } \\
\text { namely the } \\
\text { Preparedness for } \\
\text { Care Scale, the } \\
\text { Caregiver } \\
\text { Competence Scale } \\
\text { and Rewards of Care } \\
\text { Scale which need to } \\
\text { be tested } \\
\text { psychometrically so } \\
\text { that they can be used } \\
\text { in various countries } \\
\text { and further research } \\
\text { is available. }\end{array}$ & $\begin{array}{l}\text { Quantitative, } \\
\text { correlation }\end{array}$ & $\begin{array}{l}125 \\
\text { participa } \\
\text { nts }\end{array}$ & $\begin{array}{l}\text { Questionnair } \\
\mathrm{e}\end{array}$ & $\begin{array}{l}\text { The Preparedness for Care } \\
\text { Scale, the Caregiver } \\
\text { Competence Scale and } \\
\text { Rewards of Caregiving } \\
\text { Scale is a basic instrument } \\
\text { that can and is worthy of } \\
\text { being used to see readiness, } \\
\text { competence, and rewards } \\
\text { for families who care for } \\
\text { patients at home. }\end{array}$ \\
\hline
\end{tabular}

\section{RESULTS}

Based on the results of a review of several existing literature and journals, several topics were found related to family readiness in caring for patients at home. Some of the topics / themes include family care in caring for patients, instruments for measuring family preparedness, self-affection for families who care for patients at home, and psychoeducation in increasing family readiness to care for patients at home.

\begin{tabular}{lll}
\hline No & \multicolumn{1}{c}{ Theme } & \multicolumn{1}{c}{ Authors } \\
\hline $\mathbf{1}$ & Foster family burden in caring for patients & (Grant et al., 2013); (Fujinami et \\
& & al., 2015); (Dionne-Odom et al., \\
& & $2017)$ \\
\hline $\mathbf{2}$ & Instrument in measuring family preparedness & (Anette Henriksson et al., 2015); \\
& & (Annette Henriksson et al., 2012) \\
\hline $\mathbf{3}$ & Self-efficacy in families who care for patients at home & (Hendrix et al., 2016); (Chih et al., \\
& & 2013) \\
\hline
\end{tabular}


4 Psychoeducation in increasing family readiness to care for (Anette Henriksson \& Arestedt, patients at home 2013)

\section{DISCUSSION}

\section{Foster family burden in caring for patients}

Families in this case caregivers of patients who need care at home often have a high upbringing. They tend to experience a decrease in psychological well-being and have a low quality of life (Grant et al., 2013). Families as caregivers of patients at home, who provide advanced health services for sufferers have the types of problems that need to be considered. Self-care, maintenance of quality of life, components of low caregiver roles, and components of stress experienced by caregivers are problems that need to be addressed and this can be used as a reference for how nurses can develop existing interventions in dealing with these problems (Fujinami et al., 2015). The number of families who have a role as caregivers of patients at home and not cared for self-care, the level of depression and anxiety in cancer patients and other life-threatening diseases will pose a risk of new problems. It is necessary to provide appropriate interventions to improve her well-being, readiness, and affection (Dionne-Odom et al., 2017).

\section{Instrument in measuring family readiness}

Family readiness in handling patients at home is something we need to pay attention to. The nurse through her role needs to identify how prepared the family is to carry out the care of the patient independently at home. The Preparation Caregiving Scale (PCS) is a standard instrument to measure the level of family readiness in caring for patients at home (Henriksson et al., 2015). The Preparedness for Care Scale, the Caregiver Competence Scale and Rewards of Caregiving Scale is a basic instrument that can and is worthy of being used to see readiness, competence, and rewards for families who care for patients at home. Families have a big responsibility in managing patients who need care at home. Family readiness, competence, and rewards available to reduce negative risks related to care provided (Henriksson et al., 2012)

\section{Self-affirmation to the family who care for patients at home}

Having responsibility as a family with patients with palliative care creates difficulties both for patients and families who care for them at home. Self-efficacy is an important concept in parenting because it is a prerequisite for delivering actions that are actually good and right for patients. Enhanced-CT is known as a protocol that teaches the knowledge and skills of caregivers to manage symptoms and strategies to manage their own psychological stress as caregivers of cancer patients at home. Enhanced-CT protocol can improve selfefficacy in stress management in palliative care at home (Hendrix et al., 2016). There is an online patient symptom reporting system model that is also used as a research result that can be applied. This online symptom reporting system has a special procedure that allows families to communicate efficiently and on time the symptoms experienced by patients during treatment at home. This can reduce family stress levels in giving patient care independently (Chih et al., 2013).

\section{Psycho-education in increasing family readiness to care for patients at home}

The level of patient readiness is significantly related to life expectancy, higher appreciation, and reduced anxiety. Readiness in treating patients at home is very important when caregivers experience a problematic situation in patients or the patient shows life- 


\section{Journal Of Nursing Practice}

http://thejnp.org

threatening symptoms. The psychology of education for patients at home (Henriksson and Årestedt, 2013).

Family readiness in caring for patients at home including the burden of family care. Families often have a high upbringing because of the demands of care, making them vulnerable to new problems. We need to examine how the family preparedness process has the demands of caring for what interventions can be given. The self-efficacy of families that is often difficult for families to understand. The provision of psycho-education also needs to be implemented and can be maximized and the family is fulfilled.

\section{CONCLUSION}

Family readiness in caring for patients at home is an important thing to note. family members who need care at home often have a high upbringing. They tend to experience decrease in the psychological well-being and have a low quality of life (Grant et al., 2013). The Prepared Caregiving Scale (PCS) we can measure the level of family readiness in caring for patients at home, the need to improve self-affection in families who have patient care at home, as well as health care for children at home. 


\section{Journal Of Nursing Practice}

http://thejnp.org

ISSN: 2614-3488 (print); 2614-3496 (online)

Vol.3 No.2. April 2020. Page.143-152

\section{REFERENCES}

Anand, P., Kunnumakara, A. B., Sundaram, C., Harikumar, K. B., Tharakan, S. T., Lai, O. S., ... Aggarwal, B. B. (2008). Cancer is a Preventable Disease that Requires Major Lifestyle Changes. Pharmaceutical Research, 25(9), h. 2097-2116. https://doi.org/10.1007/s11095-008-9661-9

Aruan, K. P., \& Isfandiari, M. A. (2017). HUBUNGAN DUKUNGAN SOSIAL TERHADAP PENGOBATAN KANKER PAYUDARA DI YAYASAN KANKER WISNUWARDHANA. Jurnal PROMKES, 3(2), 218. https://doi.org/10.20473/jpk.V3.I2.2015.218-228

Chih, M.-Y., DuBenske, L. L., Hawkins, R. P., Brown, R. L., Dinauer, S. K., Cleary, J. F., \& Gustafson, D. H. (2013). Communicating advanced cancer patients' symptoms via the Internet: A pooled analysis of two randomized trials examining caregiver preparedness, physical burden, and negative mood. Palliative Medicine, 27(6), 533-543. https://doi.org/10.1177/0269216312457213

Dionne-Odom, J. N., Demark-Wahnefried, W., Taylor, R. A., Rocque, G. B., Azuero, A., Acemgil, A., ... Bakitas, M. A. (2017). The self-care practices of family caregivers of persons with poor prognosis cancer: differences by varying levels of caregiver well-being and preparedness. Supportive Care in Cancer, 25(8), 2437-2444. https://doi.org/10.1007/s00520-017-3650-7

Fujinami, R., Sun, V., Zachariah, F., Uman, G., Grant, M., \& Ferrell, B. (2015). Family caregivers' distress levels related to quality of life, burden, and preparedness: Family caregiver distress in NSCLC. Psycho-Oncology, 24(1), 54-62. https://doi.org/10.1002/pon.3562

Girsang, B. M. (2015). GAMBARAN PERSIAPAN PERAWATAN FISIK DAN MENTAL PADA PASIEN PRE OPERASI KANKER PAYUDARA, 2(2355), 13.

Grant, M., Sun, V., Fujinami, R., Sidhu, R., Otis-Green, S., Juarez, G., ... Ferrell, B. (2013). Family Caregiver Burden, Skills Preparedness, and Quality of Life in NonSmall Cell Lung Cancer. Oncology Nursing Forum, 40(4), 337-346. https://doi.org/10.1188/13.ONF.337-346

Hendrix, C. C., Bailey, D. E., Steinhauser, K. E., Olsen, M. K., Stechuchak, K. M., Lowman, S. G., ... Tulsky, J. A. (2016). Effects of enhanced caregiver training program on cancer caregiver's self-efficacy, preparedness, and psychological wellbeing. Supportive Care in Cancer, 24(1), 327-336. https://doi.org/10.1007/s00520$\underline{015-2797-3}$

Henriksson, Anette, \& Årestedt, K. (2013). Exploring factors and caregiver outcomes associated with feelings of preparedness for caregiving in family caregivers in palliative care: A correlational, cross-sectional study. Palliative Medicine, 27(7), 639-646. https://doi.org/10.1177/0269216313486954

Henriksson, Anette, Hudson, P., Öhlen, J., Thomas, K., Holm, M., Carlander, I., ... Årestedt, K. (2015). Use of the Preparedness for Caregiving Scale in Palliative Care: A Rasch Evaluation Study. Journal of Pain and Symptom Management, 50(4), 533-541. https://doi.org/10.1016/j.jpainsymman.2015.04.012 


\section{Journal Of Nursing Practice}

http://thejnp.org

ISSN: 2614-3488 (print); 2614-3496 (online)

Vol.3 No.2. April 2020. Page.143-152

Henriksson, Annette, Andershed, B., Benzein, E., \& Årestedt, K. (2012). Adaptation and psychometric evaluation of the Preparedness for Caregiving Scale, Caregiver Competence Scale and Rewards of Caregiving Scale in a sample of Swedish family members of patients with life-threatening illness. Palliative Medicine, 26(7), 930938. https://doi.org/10.1177/0269216311419987

Law, E., Levesque, J. V., Lambert, S., \& Girgis, A. (2018). The "sphere of care": A qualitative study of colorectal cancer patient and caregiver experiences of support within the cancer treatment setting. PLOS ONE, 13(12), e0209436. https://doi.org/10.1371/journal.pone.0209436

McGuire, S. (2016). World cancer report 2014. Geneva, Switzerland: World Health Organization, international agency for research on cancer, WHO Press, 2015. https://doi.org/10.3945/an.116.012211

Mazanec, S., Reichlin, D., Gittleman, H., \& Daly, B. (2018a). Perceived Needs, Preparedness, and Emotional Distress of Male Caregivers of Postsurgical Women With Gynecologic Cancer. Oncology Nursing Forum, 45(2), 197-205. https://doi.org/10.1188/18.ONF.197-205

Sarmento, V. P., Gysels, M., Higginson, I. J., \& Gomes, B. (2017). Home palliative care works: but how? A meta-ethnography of the experiences of patients and family caregivers. BMJ Supportive \& Palliative Care, 7(4), 00.2-00. https://doi.org/10.1136/bmjspcare-2016-001141

Schumacher, K. L., Stewart, B. J., \& Archbold, P. G. (2007). Mutuality and Preparedness Moderate the Effects of Caregiving Demand on Cancer Family Caregiver Outcomes: Nursing Research, 56(6), 425-433. https://doi.org/10.1097/01.NNR.0000299852.75300.03

Schumacher, K. L., Stewart, B. J., Archbold, P. G., Caparro, M., Mutale, F., \& Agrawal, S. (2008). Effects of Caregiving Demand, Mutuality, and Preparedness on Family Caregiver Outcomes During Cancer Treatment. Oncology Nursing Forum, 35(1), 49-56. https://doi.org/10.1188/08.ONF.49-56

Silveira, A., Amaral, S., Castro, A. R., Monteiro, E., Pimentel, F., \& Sequeira, T. (2018). Cancer Palliative Care: Technology Support for Quality of Life Assessment of Family Caregivers. Procedia Computer Science, 138, 294-302. https://doi.org/10.1016/j.procs.2018.10.042

Tanco, K., Park, J. C., Cerana, A., Sisson, A., Sobti, N., \& Bruera, E. (2017). A systematic review of instruments assessing dimensions of distress among caregivers of adult and pediatric cancer patients. Palliative and Supportive Care, 15(01), 110-124. https://doi.org/10.1017/S1478951516000079 


\section{Journal Of Nursing Practice}

http://thejnp.org

ISSN: 2614-3488 (print); 2614-3496 (online)

Vol.3 No.2. April 2020. Page.143-152 